\title{
Thermodynamic Analysis of a Thermal Pressure Generator
}

\author{
Can ÇINAR \\ Department of Mechanical Education, Faculty of Technical Education, Gazi University \\ 06500 Teknikokullar, ANKARA
}

\begin{abstract}
In this study, a conceptual air conditioning and power generation device working with heat is designed and analyzed. The device compresses the ambient air into a tank using heat. The air in the tank is adiabatically expanded to ambient pressure in a piston-cylinder mechanism and then blown into the room to be conditioned. Using the isothermal analysis, coefficient of cooling performance and thermal efficiency of work generation are determined as $\frac{Q_{L}}{Q_{H}}=0.65$ and $\frac{W_{N E T}}{Q_{H}}=0.68$ respectively at 1.721 bar tank pressure which corresponds to the maximum cyclic values of work and cooling rate.
\end{abstract}

Key Words: Air Condition, Thermal pressure generator, Ericsson engine

\section{Termal Basınç Jeneratörünün Termodinamik Analizleri}

\section{ÖZET}

Bu çalışmada, 1sı ile çalışan bir iklimlendirme ve güç üretme makinesinin tasarımı ve analizleri yapılmıştır. Makine 1Sı enerjisi kullanarak atmosferik havayı bir tank içerisine sıkıştırmaktadır. Sıkıştırılan hava bir piston-silindir mekanizması yardımı ile adyabatik olarak atmosferik basınca kadar genişletilmek suretiyle iş üretilmekte ve daha sonra soğutulacak ortama bırakılmak suretiyle ortamın iklimlendirilmesi sağlanmaktadır. İzotermal analiz kullanılarak, maksimum iş ve soğutma kapasitesinin 1,721 bar tank basıncında gerçekleştiği ve bu basınca karşılık sistemin soğutma performans katsayısının $\frac{\mathrm{Q}_{\mathrm{L}}}{\mathrm{Q}_{\mathrm{H}}}=0,65$, termik verimin $\frac{\mathrm{W}_{\mathrm{NET}}}{\mathrm{Q}_{\mathrm{H}}}=0,68$ olduğu tespit edilmiştir.

Anahtar Kelimeler : İklimlendirme, Termal basınç jeneratörü, Ericsson motoru

\section{INTRODUCTION}

Vapor compression systems have been using in domestic air conditioning. The energy consumption for domestic refrigerators is $24 \%$ of all domestic electricity use across the European Community. Due to the energy efficiency and environmental concerns, a large number of studies were conducted on alternative air conditioning systems (1-4).

In the scope of thermal pressure generators only a few studies are observed. Walker (5) reported that, an externally driven arrangement having gas operated valves was patented by Bush as a pressure generator in 1949. A development project, named VHGE, was carried out by Smith in Massachusetts Institute of Technology. The practical results were much lower than theoretically predicted. The difference was attributed to the inadequate heat transfer rate between the wall and gas in the cylinder $(6,7)$.
The analysis of such thermodynamic systems can be performed using combinations of the general state equation of ideal gases, the first law of thermodynamics given for unsteady open systems and the mass balance (8-13).

In this study, a conceptual device with two functions, working with a heat source having 1000-1200 $\mathrm{K}$ temperature, is designed and analyzed to be used in air-conditioning and work generation. The device consists of a thermal pressure generator and an adiabatic expansion unit. The thermal pressure generator works with an open cycle consisting of four thermodynamic processes. The processes are performed by means of the mechanical arrangement shown in Fig. 1, where displacement of working gas is performed by a displacer and two check valves. The volume above and below the displacer are kept at $T_{H}$ and $T_{C}$ respectively by means of heating the above and cooling the below externally. 
The side surface of the displacer will be coated with a porous material to function as regenerator.

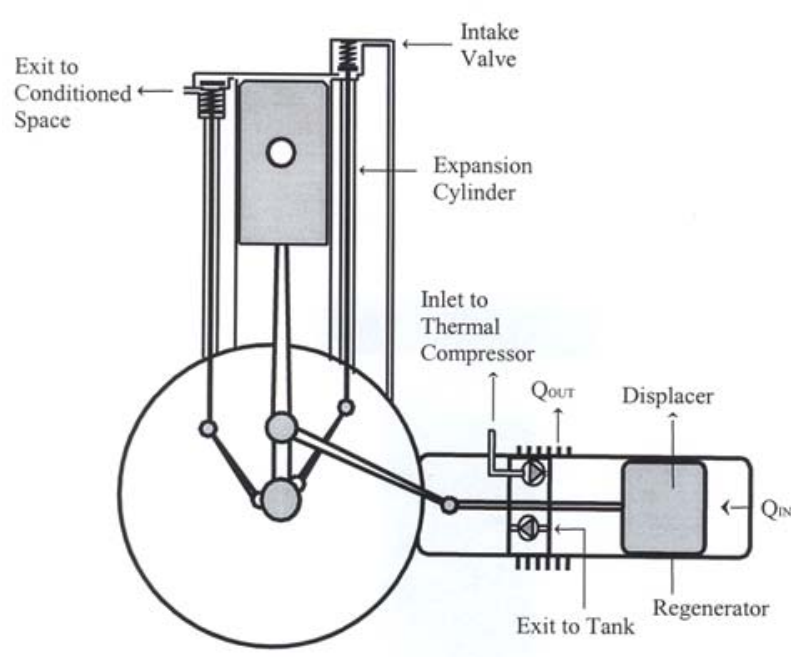

Fig. 1. Schematic view of the mechanical arrangement

In the first of thermodynamic processes the displacer moves from up to down in the cylinder and a deal of the fluid taking place in the cold volume flows through the regenerator to the hot volume above the displacer. When the fluid flows through the regenerator, its temperature varies from $T_{C}$ to $T_{H}$ by means of receiving heat from the regenerator matrix. The pressure in the device increases proportional to the mass of fluid arriving to the hot volume and at the end of process the check valve is disclosed by the pressure. In the second of thermodynamic processes the displacer continues to move until the lowest point of the cylinder. During the second process a portion of fluid in the device is pumped into a tank under constant pressure. To keep the device volume as small as possible, the crankcase may be used as the tank. In the third of thermodynamic processes the displacer moves from down to up in the cylinder. When displacer moves, the fluid taking place in the hot volume above the displacer passes to the cold volume below the displacer through the regenerator. The temperature of the fluid flowing through the regenerator varies from $T_{H}$ to $T_{C}$ by means of giving heat to the regenerator matrix. Proportional to the mass of fluid displacing from the hot volume to the cold volume the pressure in the device decreases down. In the last of processes the displacer continues to move until the highest point of the cylinder. Meanwhile the last process the pressure in the displacer cylinder becomes slightly lower than the ambient pressure and the inflow of ambient air is performed.

To condition any place by using the air compressed into the tank, first the air in the tank is expanded in the adiabatic expansion unit of the machine. Since the temperature of air in the tank is equal to the ambient temperature, after the adiabatic expansion its temperature becomes lower than the ambient temperature. Conditioning is performed by means of blowing the low temperature air into the required place.

\section{ASSUMPTIONS AND THERMODYNAMIC ANALYSIS}

The pressure difference due to flow friction between the volumes is low enough compared to thermodynamic pressure that the instantaneous pressure in the all of three volumes are assumed to be equal to each other. The solid boundary of the hot volume is assumed to be a heat source at the temperature $T_{H}$. The fluid temperature within the hot volume is the same with solid boundary temperature. The solid boundary of cold volume is a heat sink at the temperature $T_{C}$. The fluid temperature within the cold volume is also the same with solid boundary temperature. Within the regenerator the temperature varies from $T_{C}$ to $T_{H}$ linearly. The regenerator is divided into $7 \mathrm{sub}$ volumes and the mid point temperature is assumed to be valid everywhere in a sub volume. The working fluid enters the hot and cold volumes at $\mathrm{T}_{\mathrm{H}}$ and $\mathrm{T}_{\mathrm{C}}$ respectively and exits at the same temperatures. The invariable parameters of the analysis are: the cold volume temperature $T_{C}$, the hot volume temperature $T_{H}$, temperatures of regenerator sub volumes $T_{R i}$, the intake pressure $p_{i}$, the exit pressure $\mathrm{p}_{\mathrm{o}}$, the swept volume $\mathrm{V}_{\mathrm{S}}$, regenerator sub volumes $\mathrm{V}_{\mathrm{Ri}}$, the cross sectional area ratio $\in$ and the gas constant $\mathrm{R}$ of the working fluid.

Using the general state equation of ideal gases the pressure in the device is stated as,

$$
\mathrm{P}=\frac{\mathrm{mR}}{\left[\left(\frac{\mathrm{V}_{\mathrm{C}}}{\mathrm{T}_{\mathrm{C}}}\right)+\left(\frac{\mathrm{V}_{\mathrm{H}}}{\mathrm{T}_{\mathrm{H}}}\right)+\left(\sum \frac{\mathrm{V}_{\mathrm{R} \dot{\mathrm{I}}}}{\mathrm{T}_{\mathrm{RI}}}\right)\right]}
$$

The sum of cold volume, hot volume and the displacer rod volume equals to the swept volume of the displacer,

$$
\mathrm{V}_{\mathrm{S}}=\mathrm{V}_{\mathrm{C}}+\mathrm{V}_{\mathrm{H}}+\mathrm{V}_{\text {rod }}
$$

From equations (1) and (2),

$$
\begin{aligned}
& \mathrm{p}=\frac{\mathrm{mR}}{\mathrm{p}=\frac{\mathrm{mR}}{\mathrm{V}_{\mathrm{H}}\left[\frac{1}{\mathrm{~T}_{\mathrm{H}}}-\frac{(\epsilon-1)}{\mathrm{T}_{\mathrm{C}} \in}\right]+\frac{\mathrm{V}_{\mathrm{S}}}{\mathrm{T}_{\mathrm{C}}}\left(1-\frac{1}{\epsilon}\right)+\sum \frac{\mathrm{V}_{\mathrm{RI}}}{\mathrm{T}_{\mathrm{R} \dot{I}}}}} \\
& \mathrm{\textrm {C } _ { \mathrm { C } }}\left[\frac{1}{\mathrm{~T}_{\mathrm{C}}}-\frac{\epsilon}{\mathrm{T}_{\mathrm{H}}(\in-1)}\right]+\frac{\mathrm{V}_{\mathrm{S}}}{\mathrm{T}_{\mathrm{H}}}+\sum \frac{\mathrm{V}_{\mathrm{RI}}}{\mathrm{T}_{\mathrm{RI}}}
\end{aligned}
$$

are obtained. Equations (3) and (4) are eligible to calculate the hot and cold volume works respectively. In 
process 1-2, the total mass in the device remains constant as $m_{1}$. By means of integrating equation (3) in the interval $0 \leq \mathrm{V}_{\mathrm{H}} \leq \mathrm{V}_{\mathrm{H} 2}$ and equation (4) in the intervals $\mathrm{V}_{\mathrm{C} 1} \leq \mathrm{V}_{\mathrm{C}} \leq \mathrm{V}_{\mathrm{C} 2}$, the hot and cold volume works are stated as,

$$
\begin{aligned}
& \mathrm{W}_{\mathrm{H} 12}=\frac{\mathrm{m}_{1} \mathrm{R}}{\left[\frac{1}{\mathrm{~T}_{\mathrm{H}}}-\frac{(\in-1)}{\mathrm{T}_{\mathrm{C}} \in}\right]} \ln \frac{\mathrm{p}_{1}}{\mathrm{p}_{2}}, \\
& \mathrm{~W}_{\mathrm{C} 12}=\frac{\mathrm{m}_{1} \mathrm{R}}{\left[\frac{1}{\mathrm{~T}_{\mathrm{C}}}-\frac{\epsilon}{\mathrm{T}_{\mathrm{H}}(\in-1)}\right]} \ln \frac{\mathrm{p}_{1}}{\mathrm{p}_{2}} .
\end{aligned}
$$

The rate of heat transferred from and to regenerator is theoretically the same. When calculating the efficiency of the device, the regenerative heat is left out of treatment. In process 1-2, using the first law of thermodynamics, the rate of heat transfer to or from the working fluid in hot and cold volumes are respectively stated as,

$$
\begin{aligned}
& \mathrm{Q}_{\mathrm{H} 12}=\mathrm{W}_{\mathrm{H} 12}-\mathrm{RT}_{\mathrm{H}} \mathrm{m}_{\mathrm{H} 2}, \\
& \mathrm{Q}_{\mathrm{C} 12}=\mathrm{W}_{\mathrm{C} 12}-\mathrm{RT}_{\mathrm{C}}\left(\mathrm{m}_{\mathrm{C} 2}-\mathrm{m}_{\mathrm{C} 1}\right) .
\end{aligned}
$$

In process 2-3 the pressure remains constant that the hot volume work, the cold volume work, the heat transfer in hot volume and in cold volume are stated respectively as,

$$
\begin{aligned}
& \mathrm{W}_{\mathrm{H} 23}=\mathrm{RT}_{\mathrm{H}}\left(\mathrm{m}_{\mathrm{H} 3}-\mathrm{m}_{\mathrm{H} 2}\right), \\
& \mathrm{W}_{\mathrm{C} 23}=\mathrm{RT}_{\mathrm{C}}\left(\mathrm{m}_{\mathrm{C} 3}-\mathrm{m}_{\mathrm{C} 2}\right), \\
& \mathrm{Q}_{\mathrm{H} 23}=0, \\
& \mathrm{Q}_{\mathrm{C} 23}=0 .
\end{aligned}
$$

In the process $3-4$, the total mass in the device remains constant as $\mathrm{m}_{3}$. By means of integrating equation (3) in the interval; $\mathrm{V}_{\mathrm{H} 3} \leq \mathrm{V}_{\mathrm{H}} \leq \mathrm{V}_{\mathrm{H} 4}$ and equation (4) in the interval; $\mathrm{V}_{\mathrm{C} 3} \leq \mathrm{V}_{\mathrm{C}} \leq \mathrm{V}_{\mathrm{C} 4}$, the hot and cold volume works are stated as,

$$
\begin{aligned}
& \mathrm{W}_{\mathrm{H} 34}=\frac{\mathrm{m}_{3} \mathrm{R}}{\left[\frac{1}{\mathrm{~T}_{\mathrm{H}}}-\frac{(\in-1)}{\mathrm{T}_{\mathrm{C}} \in}\right]} \ln \frac{\mathrm{p}_{3}}{\mathrm{p}_{4}}, \\
& \mathrm{~W}_{\mathrm{C} 34}=\frac{\mathrm{m}_{3} \mathrm{R}}{\left[\frac{1}{\mathrm{~T}_{\mathrm{C}}}-\frac{\epsilon}{\mathrm{T}_{\mathrm{H}}(\in-1)}\right]} \ln \frac{\mathrm{p}_{3}}{\mathrm{p}_{4}} .
\end{aligned}
$$

The heat transfer to or from the working fluid in hot and cold volumes are stated as,

$$
\begin{aligned}
& \mathrm{Q}_{\mathrm{H} 34}=\mathrm{W}_{\mathrm{H} 34}-\mathrm{RT}_{\mathrm{H}}\left(\mathrm{m}_{\mathrm{H} 4}-\mathrm{m}_{\mathrm{H} 3}\right), \\
& \mathrm{Q}_{\mathrm{C} 34}=\mathrm{W}_{\mathrm{C} 34}-\mathrm{RT}_{\mathrm{C}} \mathrm{m}_{\mathrm{C} 4} .
\end{aligned}
$$

In process $4-1$, the pressure remains constant that the hot volume work, the cold volume work, the heat transfer in hot volume and in cold volume are stated respectively as,

$$
\begin{aligned}
& \mathrm{W}_{\mathrm{H} 41}=-\mathrm{m}_{\mathrm{H} 4} \mathrm{RT}_{\mathrm{H}}, \\
& \mathrm{W}_{\mathrm{C} 41}=\mathrm{RT}_{\mathrm{C}}\left(\mathrm{m}_{\mathrm{C} 1}-\mathrm{m}_{\mathrm{C} 4}\right), \\
& \mathrm{Q}_{\mathrm{H} 41}=0, \\
& \mathrm{Q}_{\mathrm{C} 41}=0 .
\end{aligned}
$$

In equation (3), substituting $\mathrm{V}_{\mathrm{H}}=0$ and $\mathrm{p}=\mathrm{p}_{1}$, the total mass in the device is stated as,

$$
\mathrm{m}_{1}=\frac{\mathrm{p}_{1}}{\mathrm{R}}\left[\frac{\mathrm{V}_{\mathrm{S}}}{\mathrm{T}_{\mathrm{C}}}\left(1-\frac{1}{\epsilon}\right)+\sum \frac{\mathrm{V}_{\mathrm{R} \dot{\mathrm{I}}}}{\mathrm{T}_{\mathrm{R} \dot{\mathrm{I}}}}\right] .
$$

After the pumping process, the total mass remaining in the device is determined using equation (4) by means of substituting $\mathrm{V}_{\mathrm{C}}=0$ and $\mathrm{p}=\mathrm{p}_{3}$ as,

$\mathrm{m}_{3}=\frac{\mathrm{p}_{3}}{\mathrm{R}}\left[\frac{\mathrm{V}_{\mathrm{S}}}{\mathrm{T}_{\mathrm{H}}}+\sum \frac{\mathrm{V}_{\mathrm{Ri}}}{\mathrm{T}_{\mathrm{RI}}}\right]$.

In hot and cold volumes the rate of mass of working fluid at several positions of displacer can be determined using the general state equation of ideal gases as well as equations (3) and (4). Results are,

$\mathrm{m}_{\mathrm{h} 2}=\frac{\left(\mathrm{p}_{2}-\mathrm{p}_{1}\right)\left[\frac{\mathrm{V}_{\mathrm{S}}}{\mathrm{T}_{\mathrm{C}}}\left(1-\frac{1}{\epsilon}\right)+\sum \frac{\mathrm{V}_{\mathrm{Ri}}}{\mathrm{T}_{\mathrm{Ri}}}\right]}{\mathrm{R}\left[\frac{\mathrm{T}_{\mathrm{H}}}{\mathrm{T}_{\mathrm{C}}}\left(1-\frac{1}{\epsilon}\right)-1\right]}$

$\mathrm{m}_{\mathrm{h} 3}=\frac{\mathrm{p}_{3}\left[\frac{\mathrm{V}_{\mathrm{S}}}{\mathrm{T}_{\mathrm{C}}}\left(1-\frac{1}{\epsilon}\right)-\frac{\mathrm{V}_{\mathrm{S}}}{\mathrm{T}_{\mathrm{H}}}\right]}{\mathrm{R}\left[\frac{\mathrm{T}_{\mathrm{H}}}{\mathrm{T}_{\mathrm{C}}}\left(1-\frac{1}{\epsilon}\right)-1\right]}$

$\mathrm{m}_{\mathrm{h} 4}=\frac{\frac{\mathrm{p}_{4} \mathrm{~V}_{\mathrm{S}}}{\mathrm{T}_{\mathrm{C}}}\left(1-\frac{1}{\epsilon}\right)-\mathrm{p}_{3} \frac{\mathrm{V}_{\mathrm{S}}}{\mathrm{T}_{\mathrm{H}}}-\left(\mathrm{p}_{3}-\mathrm{p}_{4}\right) \sum \frac{\mathrm{V}_{\mathrm{RI}}}{\mathrm{T}_{\mathrm{R}}}}{\mathrm{R}\left[\frac{\mathrm{T}_{\mathrm{H}}}{\mathrm{T}_{\mathrm{C}}}\left(1-\frac{1}{\epsilon}\right)-1\right]}$ 


$$
\begin{aligned}
\mathrm{m}_{\mathrm{C} 1}=\frac{\mathrm{p}_{1}\left[\frac{\mathrm{V}_{\mathrm{S}}}{\mathrm{T}_{\mathrm{C}}}\left(1-\frac{1}{\epsilon}\right)-\frac{\mathrm{V}_{\mathrm{S}}}{\mathrm{T}_{\mathrm{H}}}\right]}{\mathrm{R}\left[1-\frac{\mathrm{T}_{\mathrm{C}}}{\mathrm{T}_{\mathrm{H}}} \frac{\epsilon}{\epsilon-1}\right]} \\
\mathrm{m}_{\mathrm{C} 2}=\frac{\left(\mathrm{p}_{1}-\mathrm{p}_{2}\right) \sum \frac{\mathrm{V}_{\mathrm{Ri}}}{\mathrm{T}_{\mathrm{Ri}}}+\mathrm{p}_{1} \frac{\mathrm{V}_{\mathrm{S}}}{\mathrm{T}_{\mathrm{C}}}\left(1-\frac{1}{\epsilon}\right)-\frac{\mathrm{p}_{2} \mathrm{~V}_{\mathrm{S}}}{\mathrm{T}_{\mathrm{H}}}}{\mathrm{R}\left[1-\frac{\mathrm{T}_{\mathrm{C}}}{\mathrm{T}_{\mathrm{H}}} \frac{\epsilon}{\epsilon-1}\right]} \\
\mathrm{m}_{\mathrm{C} 4}=\frac{\left(\mathrm{p}_{3}-\mathrm{p}_{4}\right)\left[\frac{\mathrm{V}_{\mathrm{S}}}{\mathrm{T}_{\mathrm{H}}}+\sum \frac{\mathrm{V}_{\mathrm{Ri}}}{\mathrm{T}_{\mathrm{Ri}}}\right]}{\mathrm{R}\left[1-\frac{\mathrm{T}_{\mathrm{C}}}{\mathrm{T}_{\mathrm{H}}} \in-1\right]}
\end{aligned}
$$

Taking the summation of works produced all over the processes of thermal compression unit,

$$
\mathrm{W}_{\mathrm{TCU}}=\frac{\mathrm{p}_{1} \mathrm{~V}_{\mathrm{S}}\left[\left(1-\frac{1}{\epsilon}\right)+\sum\left(\frac{\mathrm{T}_{\mathrm{C}}}{\mathrm{T}_{\mathrm{H}}} \cdot \frac{\mathrm{V}_{\mathrm{Ri}}}{\mathrm{V}_{\mathrm{S}}}\right)\right]-\mathrm{p}_{2} \mathrm{~V}_{\mathrm{S}}\left[\frac{\mathrm{T}_{\mathrm{C}}}{\mathrm{T}_{\mathrm{H}}}+\sum\left(\frac{\mathrm{T}_{\mathrm{C}}}{\mathrm{T}_{\mathrm{Rl}}} \cdot \frac{\mathrm{V}_{\mathrm{R}}}{\mathrm{V}_{\mathrm{S}}}\right)\right]}{\epsilon\left(1-\frac{\mathrm{T}_{\mathrm{C}}}{\mathrm{T}_{\mathrm{H}}}\right)-1} \ln \frac{\mathrm{p}_{2}}{\mathrm{p}_{\mathrm{H}}} \cdot
$$

is obtained. This work is produced by the displacer rod and becomes smaller as the diameter of displacer rod becomes smaller. The same result may be obtained from the summation of heats as well.

The work produced in the expansion cylinder can be calculated as,

$$
\mathrm{W}_{\mathrm{EXP}}=\mathrm{m}_{\mathrm{p}} \mathrm{C}_{\mathrm{P}}\left(\mathrm{T}_{\mathrm{C}}-\mathrm{T}_{\mathrm{L}}\right)
$$

where $T_{L}$ is the after expansion temperature of air. The energy conversion efficiency of the device may be defined as,

$\eta=\frac{\mathrm{W}_{\mathrm{TCU}}+\mathrm{W}_{\mathrm{EXP}}}{\mathrm{Q}_{\mathrm{H}}}$.

The heat exchange of the cold air blown into the place to be conditioned can be calculated as,

$$
\mathrm{Q}_{\mathrm{L}}=\mathrm{m}_{\mathrm{p}} \mathrm{C}_{\mathrm{P}}\left(\mathrm{T}_{\mathrm{C}}-\mathrm{T}_{\mathrm{L}}\right) \text {. }
$$

The cooling performance coefficient of the device may be calculated as,

$$
\mathrm{COP}=\mathrm{Q}_{\mathrm{L}} / \mathrm{Q}_{\mathrm{H}} \text {. }
$$

\section{CASE STUDIES AND DETERMINATION OF DESIGN PARAMETERS}

The mass of the air compressed into the tank per cycle depends on the hot source temperature, cold source temperature, tank pressure, displacer rod diameter and dead volumes. The dead volumes are not avoidable because of heat transfer area requirement. The hot and cold source temperatures are also fix values due to the resisting limit of material to the temperature and ambient conditions. Considering the current design and manufacturing availabilities, $300 \mathrm{~K}$ cold source temperature, $1140 \mathrm{~K}$ hot source temperature, $20 \mathrm{cc}$ dead volume at hot end of displacer cylinder, $20 \mathrm{cc}$ dead volume at cold end of displacer cylinder and $50 \mathrm{cc}$ regenerator volume are assumed. The swept volume of the displacer is optional and taken as $333 \mathrm{cc}$. The tank pressure and diameter of the displacer rod are interrelated and an optimization is needed.

At an optional value of displacer rod diameter, starting from the ambient pressure, when the tank pressure is increased gradually, at a fixed value of tank pressure the mass pumped into the tank becomes zero. The pressure at that point is the maximum value of the tank pressure. In Fig. 2 the maximum tank pressures corresponding to several values of rod diameters are illustrated. As seen from Fig. 2, for values of rod diameter lower than $25 \mathrm{~mm}$, the variation of maximum tank pressure is not so much. If we select a $15 \mathrm{~mm}$ rod diameter the maximum tank pressure would be 2.72 bar. For this value of the tank pressure $\mathrm{T}_{\mathrm{L}}$ would be $202 \mathrm{~K}$, which is much lower than we needed. Therefore dependency of rod diameter on maximum tank pressure is disregarded in determination of rod diameter.

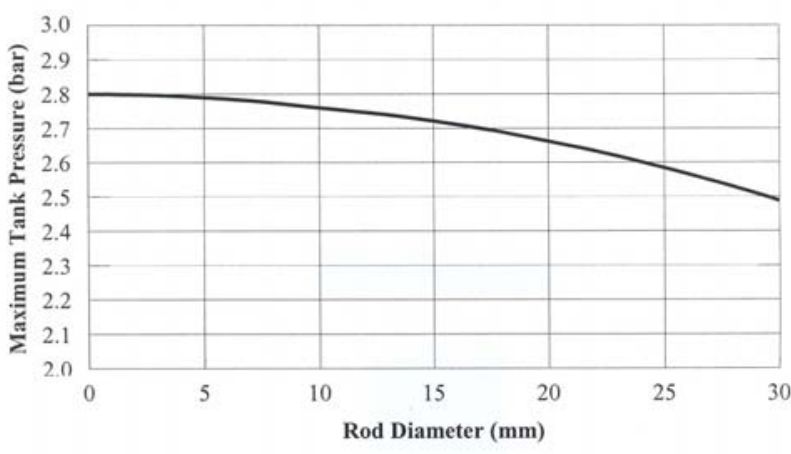

Fig. 2. Variation of maximum tank pressure with the rod diameter

The variation of pumped mass with tank pressure and rod diameter is seen in Fig. 3. As long as the rod diameter is lower than $20 \mathrm{~mm}$, the dependency of the pumped mass on the rod diameter is negligible. Therefore the rod diameter selected above is appropriate.

As shown in Fig. 3, the variation of pumped mass with the tank pressure is linear. To pump as possible as much air mass into the tank per cycle, the tank pressure must be as possible as low. On the other hand at too low tank pressures, $\mathrm{T}_{\mathrm{L}}$ becomes in adequate to cool the desired place. If the objective is to climate a living or working places a $285 \mathrm{~K}$ blown air temperature is appropriate, which corresponds to 1.2 bar tank pressure. However, in Fig. 4 it is seen that the maximum cooling rate and work per cycle correspond to 1.721 bar 
tank pressure, which is preferable as a design parameter of the machine.

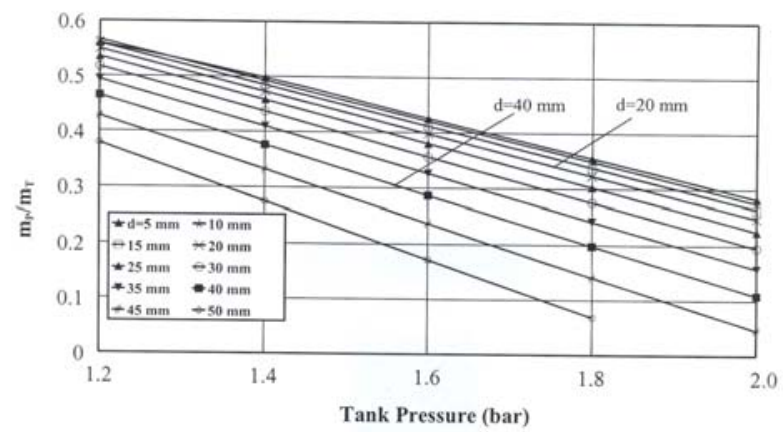

Fig. 3. Variation of mass ratio with tank pressure and rod diameter

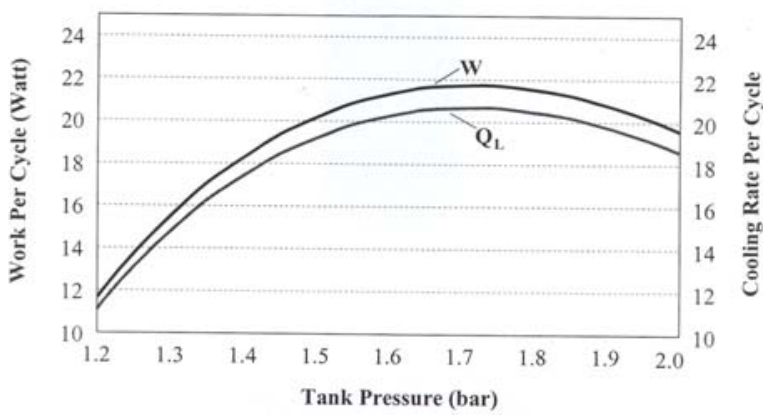

Fig. 4. Variation of work and cooling rate with tank pressure

Fig. 5 shows energy conversion efficiency of the device from heat to work and coefficient of cooling performance. Since the outlet temperature of the working fluid is lower than inlet temperature, the cycle of the system is incomplete unless the working fluid temperature returns to initial temperature. The working fluid completes the cycle outside the system by receiving heat from the ambient temperature under constant pressure which is an irreversible process. Due to the last process the cycle of the system becomes irreversible. Therefore, $\eta$ and COP are slightly related to pressure ratio.

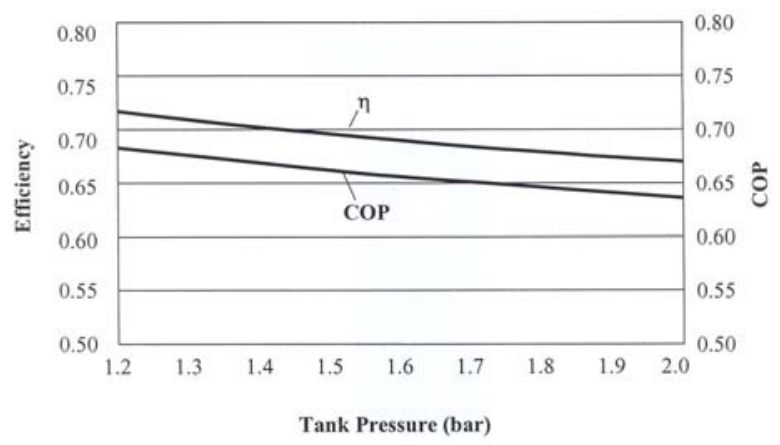

Fig. 5. Variation of COP and $\eta$ with tank pressure

The efficiency of the Carnot cycle working between the same hot and cold source is 0.736 . The thermal efficiency of the conceptual device is 0.683 at 1.721 bar tank pressure. At the same tank pressure COP is 0.65 . As the rod diameter becomes smaller the difference between $\eta$ and COP decreases. If we remind that for the current situation the practical thermal efficiency of the internal combustion engines are about 0.33 , the practical work potential of $\mathrm{Q}_{\mathrm{H}}$ would be $0.33 \times \mathrm{Q}_{\mathrm{H}}$ and COP would be 1.95 .

\section{CONCLUSION}

In this study, a conceptual air-conditioning power generation device was designed and analyzed from the thermodynamic point of view. The optimum rod diameter and tank pressure were determined as 15 $\mathrm{mm}$ and 1.72 bar respectively. Under these conditions, the thermal efficiency and coefficient of performance were calculated as 0.68 and 1.95 respectively. The temperature of the cold air to be blown into the place to be cooled is determined as $256 \mathrm{~K}$. For the same conditions, ratio of the pumped mass to the total mass in the device is calculated as 0.37 .

\section{NOMENCLATURE}

$\begin{array}{ll}\text { A } & \text { Area }\left(\mathrm{m}^{2}\right) \\ \text { COP } & \text { Coefficient of performance } \\ \mathrm{C}_{\mathrm{p}} & \text { Constant pressure specific heat }(\mathrm{kJ} / \mathrm{kgK}) \\ \mathrm{m} & \text { Mass }(\mathrm{kg}) \\ \mathrm{p} & \text { Pressure }(\mathrm{Pa}) \\ \mathrm{Q} & \text { Heat transfer }(\mathrm{J}) \\ \mathrm{R} & \text { Gas constant }(\mathrm{kJ} / \mathrm{kg} \mathrm{K}) \\ \text { T } & \text { Temperature }(\mathrm{K}) \\ \text { V } & \text { Specific volume }\left(\mathrm{m}^{3} / \mathrm{kg}\right) \\ \text { V } & \text { Volume }\left(\mathrm{m}^{3}\right) \\ \text { W } & \text { Work }(\mathrm{J}) \\ \varepsilon & \mathrm{A}_{\mathrm{s}} / \mathrm{A}_{\text {rod }}\end{array}$

$\eta \quad$ Thermal efficiency

\section{Subscripts}

C Cold

$\mathrm{H} \quad \mathrm{Hot}$

I Division numbers of regenerator

rod Displacer rod

$\mathrm{R} \quad$ Regenerator

S Swept

TCU Thermal compression unit

\section{REFERENCES}

1. Benson D.K., Potter T.F., The Effect of New Priorities and New Materials on Residential Refrigerator Design, National Renewable Energy Laboratory, American Council for an Energy Efficient Economy (ACEEE), 1321, 1992.

2. Oğuz, E., Ozkadı, F., An Experimental Study on the Refrigeration Capacity and Thermal Performance of Free Piston Stirling Coolers, Proceedings of the 2000 International Refrigeration Conference, Purdue, 497-504, 2000 .

3. Ataer, Ö.E., Göğüş, Y., Comparative Study of Irreversibilities in an Aqua-Ammonia Absorption Refrigeration System, International Journal of Refrigeration, 14, 86-92, 1991.

4. Berchowitz D.M., Unger R., Experimental Performance of a Free-Piston Stirling Cycle Cooler for Non-CFC 
Domestic Refrigeration Applications, XVIII International Congress of Refrigeration Inc., Montréal, Canada, 848852, August 1991.

5. Walker, G., Stirling Engines, Clarendon Press, Oxford, 1980.

6. Karabulut, H., Thermodynamic Analysis of Bush Engine, Gazi University Journal of Science, 16(1), 135-144, 2003.

7. Lee, K.P., Smith, J.L., Influence of Cyclic Wall to Gas Heat Transfer in the Cylinder of Valved Hot Gas Engine, Proceedings of $13^{\text {th }}$ IECEC, 1798-1804, 1978.

8. Kentfield, J.A.C., Thermodynamics of Stirling Engines Revisited: The Relative Merits of Hot Zone or Cold Zone Work Extraction. Proc., $27^{\text {th }}$ Intersociety Energy Conversion Engineering Conference, SAE, Warrendale, 5, 1992.
9. Tew, R., Jefferies, K., Miao, D., A Stirling Engine Computer Model for Performance Calculation, NASA Lewis Research Center, USA, July 1978.

10. Walker, G., Fauvel, R., Gustafson, R., Bentham, J. V., Stirling Engine Heat Pumps, International Journal of Refrigeration, 5, 91-97, 1982.

11. Urieli, I., Ideal Isothermal Analysis, http://www.ent.ohiou.edu/ urieli/stirling/ isothermal/isothermal.html, 2005.

12. Ataer. E., Karabulut. H., Thermodynamic Analysis of a V-type Stirling-Cycle Refrigerator, International Journal of Refrigeration, 28, 183-189, 2005.

13. Angelino, G., Invernizzi, C., Potential Performance of Real Gas Stirling Cycle Heat Pumps, International Journal of Refrigeration, 19, 390-399, 1996. 